\title{
流域地形則を用いた河川水温分布モデル \\ A DISTRIBUTION MODEL OF RIVER TEMPERATURES \\ DEVELOPED BY USING GEOMORPHOLOGIC LAWS OF A RIVER BASIN
}

\author{
宮本仁志 ${ }^{1}$ ・道奥康治 2 \\ Hitoshi MIYAMOTO and Kohji MICHIOKU \\ 1正会員 博士 (工学) 神戸大学准教授 工学研究科市民工学専攻 ( \\ 2フェロー会員 工学博士 神戸大学教授 工学研究科市民工学専攻（ 同上）
}

\begin{abstract}
In this paper, we proposed a basin-scale distribution model for stream temperature prediction in a river network. The model used geomorphologic laws of river basins in order to connect channel segments from the sources to river mouth. In each segment, a theoretical solution derived from a thermal energy equation with Taylor-series approximation was applied to predict longitudinal variation of river temperature. The present model was able to predict the stream temperature distribution when the geomorphologic characteristics, the topological structure of the river network, and the meteorological and hydrological conditions were given. Comparison of the model prediction with the observation showed good agreement for the whole temperature increase from the source to mouth. However, more consideration, such as land use effects, will be needed for higher accuracy of stream temperature prediction.
\end{abstract}

Key Words: basin environment, water quality, stream temperature, geomorphologic model, stream order, magnitude

\section{1. 序 論}

流域一貫の総合土砂管理や健全な水循環保全などに代 表されるように，近年，流域全域で整合した水環境整備 が重要となっている. 治水, 利水, 自然環境の諸要素が 流域内で相互にバランスした健全な水環境を保全するた めには，それらの要素を統一的に整理できる新たな指標 が必要と考えられる、筆者らは, 流域地形則に代表され る地形特性がその指標になり得ると考えて，現在適用性 の検討をはじめている1,-3).

前報了では, 重要な流域環境因子の一つとして河川水 温を選び，その全流域スケールでの連続モニタリングを 実施した. さらに，流域地形則を用いた河川水温分布の 記述を念頭において，上下流二地点間の水温変化を簡易 的に予測する手法を提案した.

本論文は，前報)での結果に基づき，流域全域での河 川水温解析を行うために河道間の水温差を流域地形則を 用いて関連付け，流域規模の河川水温解析を試みるもの である. モデル構築に際しては，河道の合・分流を正確 に表現するために，Strahlerによる河道位数則 (4)をべース にしつつ, Shereveのマグニチュード)を独立変数として 解析モデル全体を表現する方法をとった.

河川水温は，水田灌溉など農業用水や発電用水，工場
冷却水など利水への影響可に加えて，河川の生態環境を 様々な形で規定する. そのため, 河川水温は最も簡単に 計測できる環境指標として考えられる．河川水温に関す る既往の研究は非常に多く7，上流域森林の影響に関す る研究8)や魚類の生息環境に関する研究9), 地球気象変動 に関する研究10)などが例挙される。しかしながら，それ らは上流部小流域, 81 ,112)や支川の一部13)を対象とする研究 が多く，流域全域を一貫して対象としたものは少ない． 流域地形則 ${ }^{14)}$ に関する研究は, Strahler ${ }^{4)}$ の位数則, Shereveのマグニチュード理論5,15,16)などに代表される. 位数則やマグニチュード理論は, 流域における河道の相 対位置の表現に使われることが多いが，筆者らのように， 位数やマグニチュードを説明変数として環境因子の解析 に使用することは少ない。

実際の地形量を直接用いずに流域地形則という数理モ デルを用いることによって, 水系ツリー構造上の環境因 子の分布特性が客観的に表現される. これにより，例え ば，地形則のモデル係数を介しての流域間比較や，水系 ツリー構造の変更による河川分派・導水の水環境への影 響などが，将来的には評価できることが期待される.

本論文の構成は以下のとおりである。まず，前報3)の 解析モデルと同様にして各河道区間内の水温変化を一次 元熱保存式により予測する. 次に, 区間どおしの河川水 


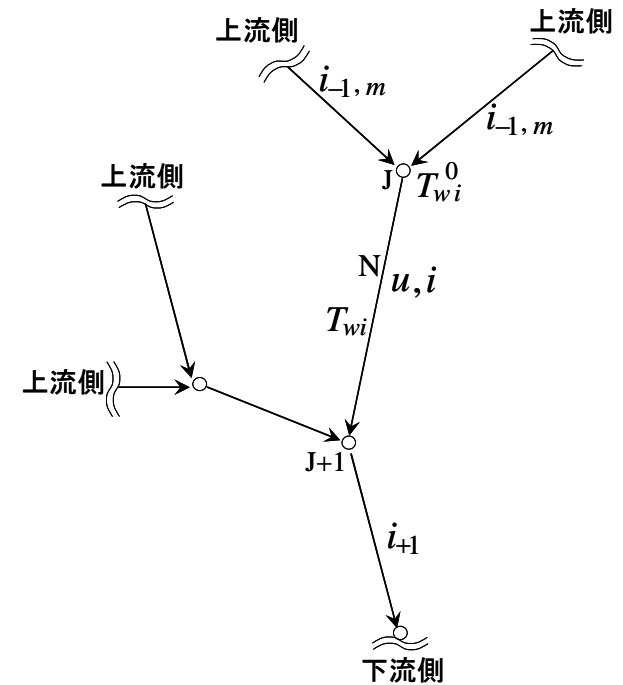

図-1 流域の一部における河道ネットワークの模式図

温を地形則によって関連付けて流域全体の水温変化を推 定する．本理論の適用性を検証するために実流域での観 測值との比較が行われる，最後に，本理論の実用性を向 上するための今後の課題が示される.

\section{2. 解析モデルの構築}

流域全体の河川水温を予測するために，地形則を用い て河道ネットワーク構造をモデル化する. 各河道区間に おける流水水温の変化は，前報 ${ }^{3)}$ と同様に一次元熱輸送 方程式の解析解より求める.

\section{（1）基礎方程式}

\section{a）流域地形}

本論文では，河川の合・分流構造を正確に表現するた

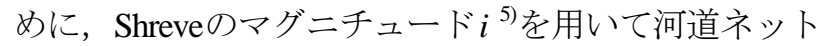
ワーク構造を表現する. その際, Strahlerの位数則 ${ }^{4}$ を介 してマグニチュード $\mathrm{i}$ と各流域地形変数とを関連づける. 位数 $u$ を用いた流域地形則, および位数 $u$ とマグ二 チュードiの関係 ${ }^{16)}$ は，以下の式で表される.

$$
\begin{aligned}
N_{u}=R_{b}{ }^{k-u}, \quad R_{b}=N_{u-1} / N_{u} \quad \text { (河道数則) } \\
\overline{L_{u}}=\overline{L_{1}} R_{L}{ }^{u-1}, \quad R_{L}=\overline{L_{u}} / \overline{L_{u-1}} \quad \text { (河道長則) } \\
\overline{A_{u}}=\bar{A}_{1} R_{a}{ }^{u-1}, \quad R_{a}=\overline{A_{u}} / \overline{A_{u-1}} \quad \text { (流域面積則) } \\
\overline{S_{u}}=\bar{S}_{1} R_{s}{ }^{1-u}, \quad R_{s}=\overline{S_{u-1}} / \overline{S_{u}} \quad \text { (河道勾配則) } \\
\bar{i}_{u}=R_{b}{ }^{u-1} \quad \text { (位数とマグニチュードの関係) }
\end{aligned}
$$

ここに, $N_{u}, \bar{L}_{u}, \bar{S}_{u}, \bar{A}_{u}, \bar{i}_{u}$ : それぞれ， $k$ 次流域内にお ける $u$ 次河道の河道数 $(1 \leq u \leq k)$, 平均河道長, 平均河 道勾配, $u$ 次流域の平均流域面積, マグニチュードの平 均值(平均水源数)であり, $R_{b}, R_{L}, R_{a}, R_{S}$ : それぞれ,
分岐比，河道長比，流域面積比，河道公配比である.

b）水理·水文量

流量と河川幅は以下の式で与える ${ }^{4,17)}$.

$$
\begin{aligned}
& Q=a A^{b} \\
& B=c Q^{d}
\end{aligned}
$$

ここに，Q：ある生起確率年に対応する流量, $A$ : 流域 面積, $B$ : 河川幅, であり, $a, b, c, d$ : 各流域・生起確率 年毎に決定される係数と指数である.

c) 河川水温

基礎式は次の一次元熱輸送方程式である.

$$
\begin{aligned}
\frac{\partial T_{w}}{\partial t}+V \frac{\partial T_{w}}{\partial x}=\frac{1}{A} \frac{\partial}{\partial x}\left(A D_{x} \frac{\partial T_{w}}{\partial x}\right) & +\frac{q_{x}}{A}\left(T_{w l}-T_{w}\right) \\
& +\frac{1}{c_{w} \rho_{w} A}\left(H_{w s} B+H_{b e d} P_{w}\right)
\end{aligned}
$$

ここに, $T_{w}$ : 河川水温, $V$ : 流下方向断面平均流速, $A$ : 断面積, $D_{x}$ : 水温の縦分散係数, $q_{x}$ : 横流入量, $T_{w l}$ : 横流入水の水温, $c_{w}$ : 水の定圧比熱, $\rho_{w}$ : 水の密 度, $H_{w s}$ : 水面からの熱フラックス, $H_{b e d}$ : 潤辺からの 熱フラックス, $B$ : 河川幅, $P_{w}$ : 潤辺長, $x$ : 流下方向座 標, $t$ : 時間座標, である. なお, 水深が深い湖沼・海 洋での鉛直方向熱輸送では水中での日射吸収や鉛直拡散 の効果が重要になるが，本論文で対象とする水深が浅く 移流作用が大きい河川での水平方向熱輸送では，それら の効果は式(8)に挙げられた各項に比べて無視される ${ }^{18)}$.

\section{（2）河川水温の流域地形モデル}

\section{a）河道区間における水温変化}

図-1に示す河道ネットワーク上のある河道区間N(合流 点J〜J+1の間)における河川水温 $T_{w i}$ の変化を，一次元熱 輸送方程式で記述する.

まず，式(8)に以下の近似を施す：(i) 水温形成に支配 的な因子は水面・潤辺およひ河道上流・流域側面からの 熱フラックスであるとし, 式(8)の右辺第一項(拡散項)お よび左辺第一項(非定常項)は無視できる程度に小さい,

(ii) 流水断面を広幅長方形断面で近似する, (iii) 河畔植 生や森林，山地地形など土地利用形態が水温に及ぼす影 響は小さいと考える．非定常項が小さいと考えることは, 同項が卓越する日周変動よりも長周期の水温変化を対象 にすることを意味する．すなわち，半旬程度の天候や流 量の変化，および，月をまたぐ気象の季節変化などに伴 う水温変動が, $H_{w s}, H_{b e d}, T_{w l}, Q, B$ の変動を介し て流域規模で記述されることを意図する.ささに，こ こでは，後述のように，(iii)の森林や地形などの影響を 無視できない区間もあり，今後の検討でモデルに加える 予定である.

以上の近似より，式(8)は次式となる.

$$
\frac{d T_{w i}}{d x}=\frac{q_{x i}}{Q_{i}}\left(T_{w l i}-T_{w i}\right)+\frac{B_{i}}{c_{w} \rho_{w} Q_{i}}\left(H_{w s i}+H_{b e d i}\right)
$$

ここに，下添字 $i$ はマグニチュード $i$ の河道区間である ことを示す. 水面および潤辺からの熱フラックス $H_{w s i}$, 
$H_{\text {bed } i}$ の取り扱いは，前報 ${ }^{3)}$ と同じである. 非線形項は 平衡水温 $T_{w e q i}$ のまわりに展開されたテイラー級数第一 近似までを採用する.

これより，式(9)は次式となる.

$$
\begin{aligned}
\frac{d T_{w i}}{d x} & =F_{1 i}\left(T_{w l i}-T_{w i}\right)+F_{2 i}\left(H_{0 i} T_{w i}+H_{1 i}\right) \\
& =\left(F_{2 i} H_{0 i}-F_{1 i}\right) T_{w i}+\left(F_{1 i} T_{w l i}+F_{2 i} H_{1 i}\right) \\
& =\alpha_{i} T_{w i}+\beta_{i}
\end{aligned}
$$

ここに,

$$
F_{1 i}=\frac{q_{x i}}{Q_{i}}, \quad F_{2 i}=\frac{B_{i}}{c_{w} \rho_{w} Q_{i}}
$$

であり， $H_{0 i}, H_{1 i}$ :それぞれ, 水面・潤辺からの熱フ ラックスを線形化したときの一次の項の係数と定数項 ${ }^{3}$ である。

式(10)に境界条件として河道上流端 $x=0$ で $T_{w i}=T_{w i}{ }^{0}$ を 与えて解くと, 以下の解を得る.

$$
T_{w i}=\frac{1}{\alpha_{i}}\left(\beta_{i}\left(\exp \left(\alpha_{i} x\right)-1\right)+\alpha_{i} \exp \left(\alpha_{i} x\right) \times T_{w i}^{0}\right)
$$

流量 $Q_{i}$, 河川幅 $B_{i}$, 横流入量 $q_{i}$, 平衡水温 $T_{w e q i}$, お よび流入水温 $T_{w i}{ }^{0}$ などが流域地形則を介してマグニ チュードiの関数として表現されれば，河川水温が予測 される。

b）地形則によるマグニチュードのモデルへの導入

次に，マグニチュード $i$ を用いて，流量 $Q_{i}$, 河川幅 $B_{i}$, 河道長 $L_{m}$ および横流入量 $q_{i}$ の地形依存性を表す。 流量 $Q_{i}$ について : 式(3a),(5)に対数変換を施し整理す ると以下の式を得る.

$$
\overline{A_{u}}=\overline{A_{1}} \overline{i_{u}}(\ln R a / \ln R b)
$$

式(14)は，位数 $u$ における平均流域面積 $\bar{A}_{u}$ と平均マグニ チュード $\overline{i_{u}}$ の関係を与え，厳密には個々のマグニチュー ド $i$ に対しては成り立たない ${ }^{16)}$ が，ここでは，i につい ても式(14)の関係を近似的に適用し，以下の関係が成立 するものとする.

$$
A_{i}=\bar{A}_{1} i^{(\ln R a / \ln R b)}
$$

式(15)を式(6)に代入して整理すると， $i$ と流量 $Q_{i}$ との間 には，以下の関係が導かれる.

$$
Q_{i}=\overline{Q_{1}} i^{b(\ln R a / \ln R b)}
$$

ここに， $\overline{Q_{1}}$ : マグニチュード $i=1$ における流量である. 河川幅 $B_{i}$ について：式(16)を式(7)に代入して整理す ると，河川幅 $B_{i}$ に関して以下の式を得る.

$$
B_{i}=\overline{B_{1}} i^{b d(\ln R a / \ln R b)}
$$

ここに, $\overline{B_{1}}:$ マグニチュード $i=1$ における $\overline{Q_{1}}$ に対応す る河川幅である。

河道長 $L_{m}$ について：河道区間長は流域全体で一定と 仮定し, 流域の全河道長 $L_{\text {total }}$ を以下の式で表す.

$$
L_{\text {total }}=\sum_{u=1}^{k} \sum_{j=1}^{n} L_{u j}=\overline{L_{1}} R_{b}^{k-1} \frac{R_{L b}^{k}-1}{R_{L b}-1}
$$

ここに， $R_{L b}=R_{L} / R_{b}$ である. 河道区間の全数を $N_{\mathrm{T}}$ とす ると, 河道長 $L_{m}$ は次式で与えられる.

$$
L_{m}=L_{\text {total }} / N_{\mathrm{T}}=\frac{\overline{L_{1}} R_{b}^{k-1}\left(R_{L b}^{k}-1\right)}{\mathrm{N}_{\mathrm{T}}\left(R_{L b}-1\right)}
$$

横流入量 $q_{x i}$ について : 横流入量は, 式(16),(19)から合 流点J, J+1での流出量・流入量の差を河道長 $L_{m}$ で除す ることにより，次式で与えられる.

$$
\begin{aligned}
q_{x i}= & \left(Q_{i}-\sum_{m} Q_{-1, m}\right) / L_{m} \\
= & \frac{\overline{Q_{1}} N_{\mathrm{T}}\left(R_{L b}-1\right)}{\overline{L_{1} R_{b}^{k-1}\left(R_{L b}{ }^{k}-1\right)} \times} \\
& \quad\left(i^{b(\ln R a / \ln R b)}-\sum_{m}\left(i_{-1, m}\right)^{b(\ln R a / \ln R b)}\right)
\end{aligned}
$$

ここに, $Q_{-1, m}, \quad i_{-1, m}$ の下添字 $m$ は流入支川の番号 を表し，例えば二河川が合流する場合 $m=1,2$ となる.

式(16),(17),(20)を式(11),(12)に代入すれば， $F_{1 i} ， F_{2 i}$ が, 以下に示すように $i$ と各地形変数によって表現される.

$$
\begin{gathered}
F_{1 i}=\frac{\left(R_{L b}-1\right) N_{\mathrm{T}}}{\bar{L}_{1} R_{b}^{k-1}\left(R_{L b}^{k}-1\right)} \times \\
\left(1-\sum_{m}\left(i_{-1, m} / i\right)^{b(\ln R a / \ln R b}\right) \\
F_{2 i}=\frac{\overline{B_{1}} i b(d-1)(\ln R a / \ln R b)}{c_{w} \rho_{w} \overline{Q_{1}}}
\end{gathered}
$$

c）境界条件

上流側の河川水温 $T_{w i}{ }^{0}$ は, 流入支川の流量 $Q_{-1, m}$ と 対応する水温 $T_{w i-1, m}$ を用いて, 以下の式で与えた.

$$
\begin{aligned}
T_{w i}^{0} & =\frac{\sum_{m} Q_{-1, m} T_{w i_{-1, m}}}{\sum_{m} Q_{-1, m}} \\
= & \frac{\sum_{m}\left(i_{-1, m}\right)^{b\left(\ln R a / \ln R_{b}\right)} \times T_{w i-1, m}}{\sum_{m}\left(i_{-1, m}\right)^{b\left(\ln R a / \ln R_{b}\right)}}
\end{aligned}
$$

\section{（3）源流水温, 横流入水温および平衡水温}

源流水温, 横流入水温はその標高における1m地下の 地温と平衡状態にあると仮定し，竹内 ${ }^{19)}$ の式を用いて以 下のように与えた.

$$
T_{w 1} \text { or } T_{w l i}=p_{1} \phi+p_{2} h+p_{3}
$$

ここに, $\phi:$ 緯度, $h:$ 標高であり, $\left(p_{1}, p_{2}, p_{3}\right)=$ (-0.99,-0.0040,59.37): 月と経度により決まる係数である. 
平衡水温は, 気温や気圧など気象観測所のデータを各 標高值に補正して次式より求めた.

$$
H_{w s i}=0
$$

式(24),(25)の計算に必要な各地点での標高は，河道勾 配則(式(4)), 位数とマグニチュードの関係(式(5)), およ び河道長 $L_{m}$ (式(19))を用いて, 以下のように求められる. まず, $i$ と河道勾配 $S_{i}$ との関係は, 式(15) と同様に以下 のようになる.

$$
S_{i}=\overline{S_{1}} \times i^{-\left(\ln R_{s} / \ln R b\right)}
$$

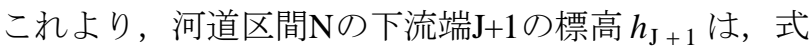
(26)と(19)を用いて，最下流点(河口)加当該河道区間ま での高度増加分を河道ネットワーク上のルートに沿い累 積して以下のように得られる.

$$
h_{\mathrm{J}+1}=\sum \frac{S_{i} L_{m}}{\sqrt{1+S_{i}^{2}}}
$$

$h_{\mathrm{J}+1}$ を用いて，任意地点での源流水温，横流入水温お よび平衡水温が求められる.

\section{（4）計算手順}

分岐比 $R_{b}$ をはじめとする流域地形変数および各河道 区間のマグニチュード $i$ が同定されれば，源流 $i=1$ から 河口 $i=i_{\max }$ に向けて河道沿いに水温変化を式(10)から積 算し, 各点での河川水温が推定される.地形解析には ArcGISを, 河川水温解析にはMathematicaを用いた.

\section{3. 適用結果と考察}

\section{(1) 対象流域}

図-2に対象とした一級河川揖保川水系の位置を，表-1 に流域概要を示す。流域は羽状型を呈しており, 上・ 中・下流域が明確に認識できる比較的単純な構造を有し ている. 図-3に，揖保川流域の河道網と水温プローブ設 置箇所を示寸．河道位数ごとに観測点を数点選び，流域 全域で27観測点を設定している．揖保川の年平均流量は 基準地点(龍野，図-3の観測点15-16のほぼ中央)で約 $29 \mathrm{~m}^{3} / \mathrm{sec}$ である。

\section{(2) 地形解析}

図-4に，ArcGISを用いて解析した，対象流域の地形則 への適合性の検討結果を示寸，解析にあたっては一次流 域面積の最小值を $1.0 \mathrm{~km}^{2}$ と設定した. 式(1)〜(4)の等比数 列型モデルへの適合性は，その決定係数 $R^{2}$ が $0.98 \sim 0.99$ であり, 非常に高い.

地形解析から, 図-4に示されている河道ネットワーク 構造と, 表-2(後述) に一部示されている地形特性值が得 られる。揖保川流域は363の小流域・河道区間に分けら れ，源流である一次河道の数 $(=$ 最大マグニチュード $\left.i_{\text {max }}\right)$ は183であった. この地形解析に加えて, 流量・河 川幅, 源流水温・横流入水温・平衡水温を評価し, 河川 水温解析に必要な情報が得られる.

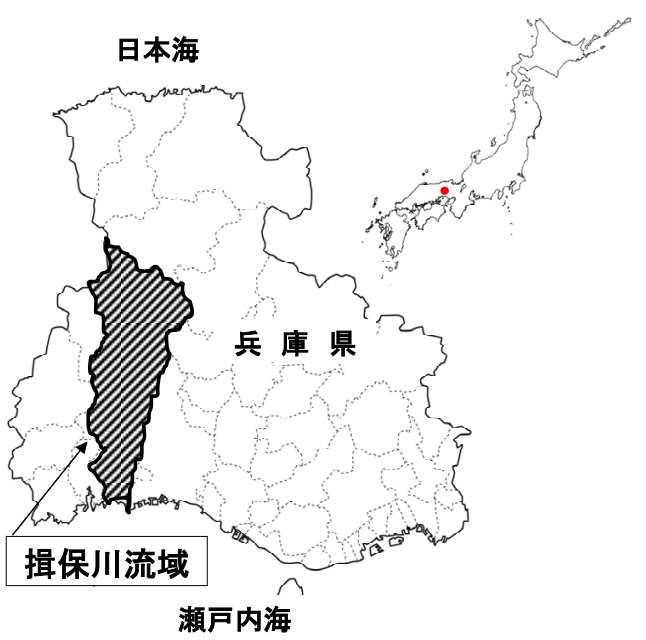

図-2 対象流域の位置

\section{（3）河川水温解析}

本論文では，昨年の観測值の中で最高水温を記録した 2006年8月の月平均水温を対象にして, 河川水温を予測 する. 表-2に入力条件を示寸，本来であれば確率評価に 基づいて式(6),(7)の指数, 係数が決定されるべきである が，ここでは流下方向の数点に限定して当該期間の平均 流量(基準地点 : 龍野において約 $14.3 \mathrm{~m}^{3} / \mathrm{sec}$ )から指数 $b$ の 值を求めた. 河川幅の指数dについては, Leopold ${ }^{17}$ を参

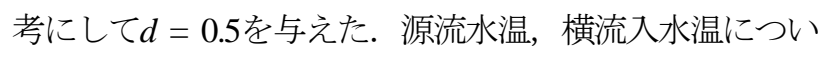
ては，式(24)の地温を与えたが，過大に評価される傾向 があったため係数を小さめに調整した.

図-5に，2006年8月の平均水温に関する観測值と解析 值を示寸．ただし，例示している解析值は各観測地点に 対応する河道区間の最下流点での值を示しており, 厳密 に同じ地点での比較となっていない. 最上流から河口ま での水温増加量は, 観測值, 解析值ともに約 $10^{\circ} \mathrm{C}$ 程度 (観測值: 27.2-17.5 $=9.7^{\circ} \mathrm{C}$ ，解析值: 25.6-15.7=9.9 ${ }^{\circ} \mathrm{C}$ ) であ り, 解析値は流域全体の昇温幅を良好に表現している. 少し詳細にみると, 上流域での昇温幅は解析值の方が大 きく, 逆に下流域では昇温が過小に評価されている. 実 際に, 観測点7, 11，17の間の観測水温の温度変化は，そ

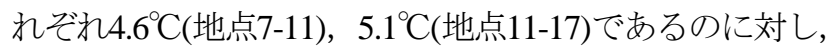

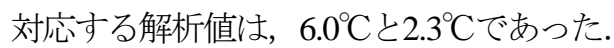

図-6に解析水温と観測水温の比較を示寸. 図-6 (a) に 示寸相関関係より, 各プロットはほぼ $45^{\circ}$ 線に沿ってあ るため，上流から下流域まで概ねの昇温構造は再現され

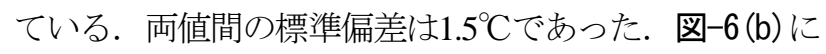
示寸各河道区間における解析值と観測值の昇温偏差から, マグニチュードi が小さい上流域で解析值の昇温が過大 評価され，逆に下流域で過小評価されているのがわかる。 解析值の昇温幅が下流域で小さいのは, 流下方向への流 量増加に伴って河川水の熱容量が大きくなるからであろ う. 観測值との誤差の要因としては種々考えられるが, 最も大きなものとして，土地利用形態による地被・植被 条件の影響を考慮していないことが考えられる，すなわ 


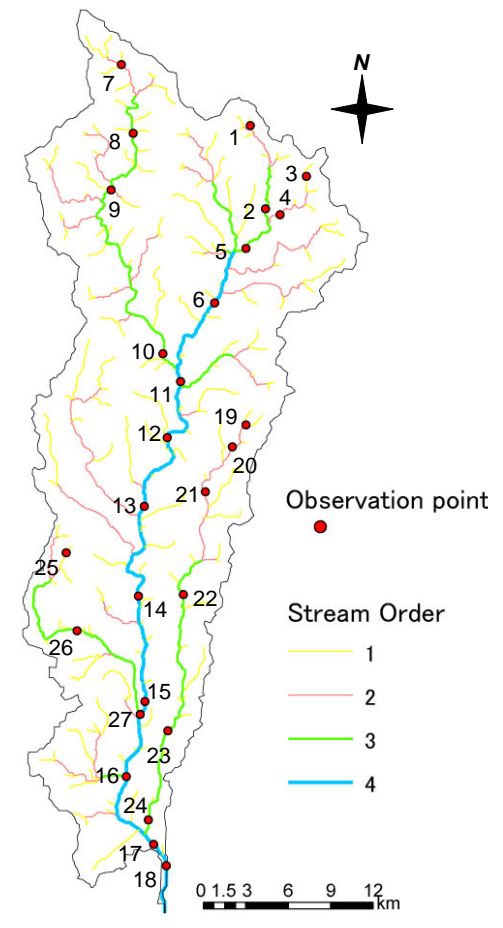

図-3 揖保川流域の河道網と 水温プローブ設置箇所

表-1 観測流域の概要

\begin{tabular}{|c|c|c|c|c|c|}
\hline 流域人口 & 流域面皘 & 幹川流路延長 & 河川数 & 総流路延岳 & 河川密度 \\
\hline [方人] & $A\left[\mathrm{~km}^{2}\right]$ & {$[\mathrm{km}]$} & & $L[\mathrm{~km}]$ & $R_{\mathrm{D}}=L / A$ \\
\hline 20 & 810 & 70 & 47 & 291 & 0.359 \\
\hline
\end{tabular}

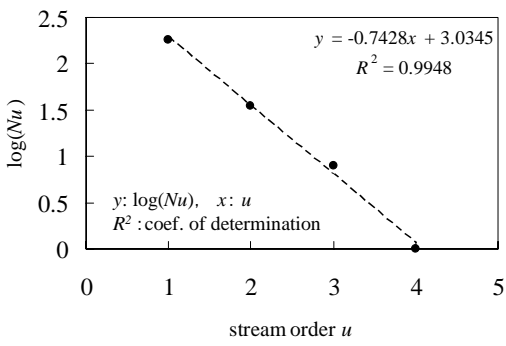

(a) 河道数則

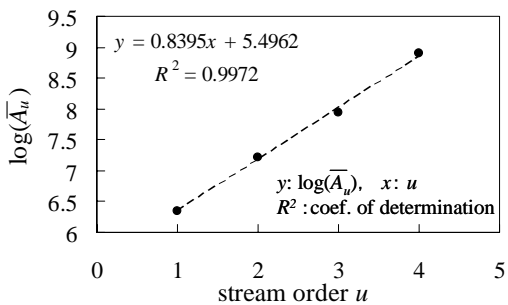

(c) 流域面積則

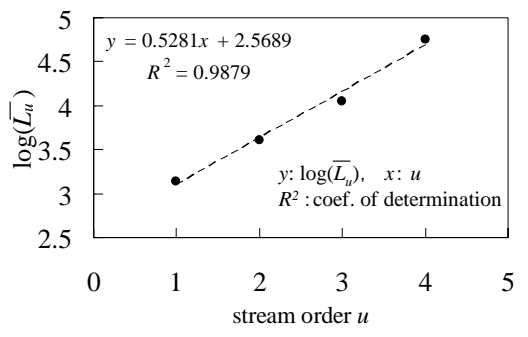

(b) 河道長則

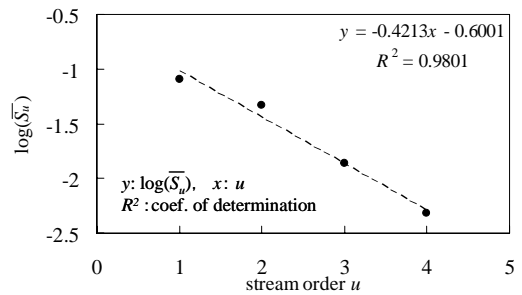

(d) 河道勾配則

図-4 流域地形則への適合性

表-2 解析の入力条件

\begin{tabular}{|c|c||c|}
\hline 項 目 & 記号 & 值など \\
\hline \hline 日 射 など & & 気象庁HP \\
\hline 流 量 & & 国土交通省 \\
\hline 分岐比 & $R_{b}$ & 5.53 \\
\hline 河道長比 & $R_{L}$ & 3.37 \\
\hline 流域面積比 & $R_{a}$ & 6.91 \\
\hline 河道勾配比 & $R_{s}$ & 2.64 \\
\hline 一次河道長 & $\bar{L}_{1}$ & $1,250 \mathrm{~m}$ \\
\hline 一次流域面積 & $\overline{A_{1}}$ & $2.17 \mathrm{~km}$ \\
\hline 一次河道勾配 & $\overline{S_{1}}$ & 0.0952 \\
\hline 一次河道流量 & $\overline{Q_{1}}$ & $0.1 \mathrm{~m}^{3} / \mathrm{sec}$ \\
\hline 一次河川幅 & $\bar{B}_{1}$ & $5.0 \mathrm{~m}$ \\
\hline 流量指数 & $b$ & 0.91 \\
\hline 河川幅指数 & $d$ & 0.5 \\
\hline 最大位数 & $k$ & 4 \\
\hline 最大マグニチュド & $i_{\max }$ & 183 \\
\hline 全河道数 & $\mathrm{N}_{\mathrm{T}}$ & 363 \\
\hline 河道網構造 & & ArcGIS \\
\hline 平衡水温 & & 標高ごと \\
\hline 源流·横流入水温 & & 標高ごとの地温 \\
\hline & & \\
& & \\
\hline
\end{tabular}

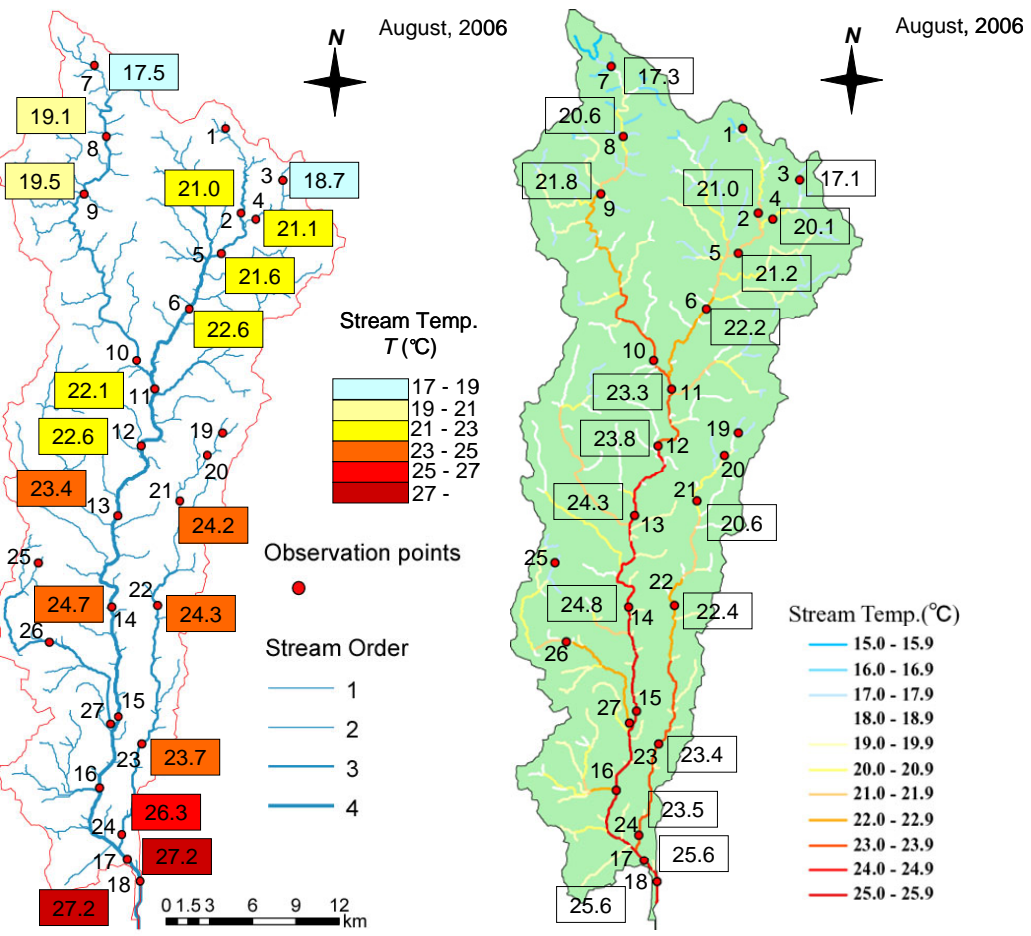

(a) 観測值

(b) 解析値

図-5＼cjkstart河川水温の観測結果とモデルによる解析結果(2006年8月平均水温) 


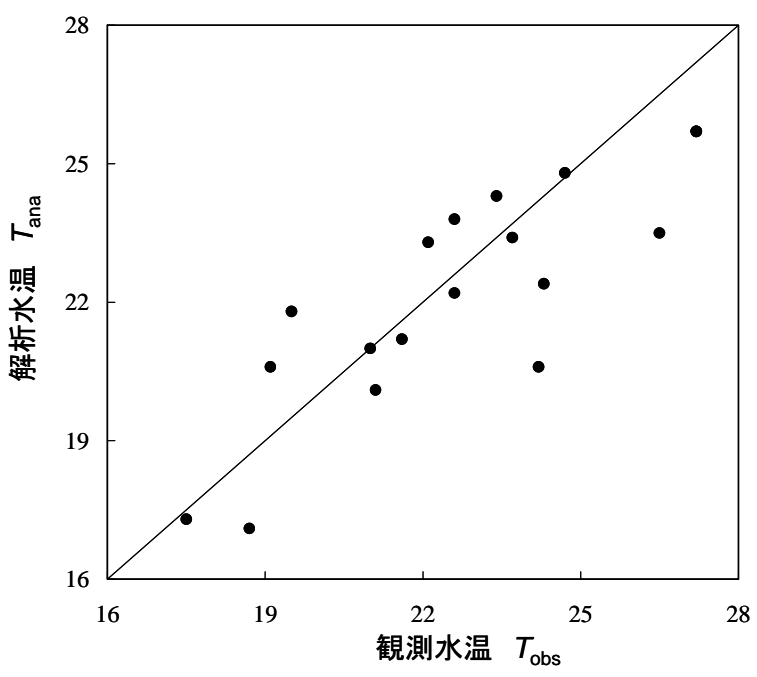

（a） 観測值と解析值の関係

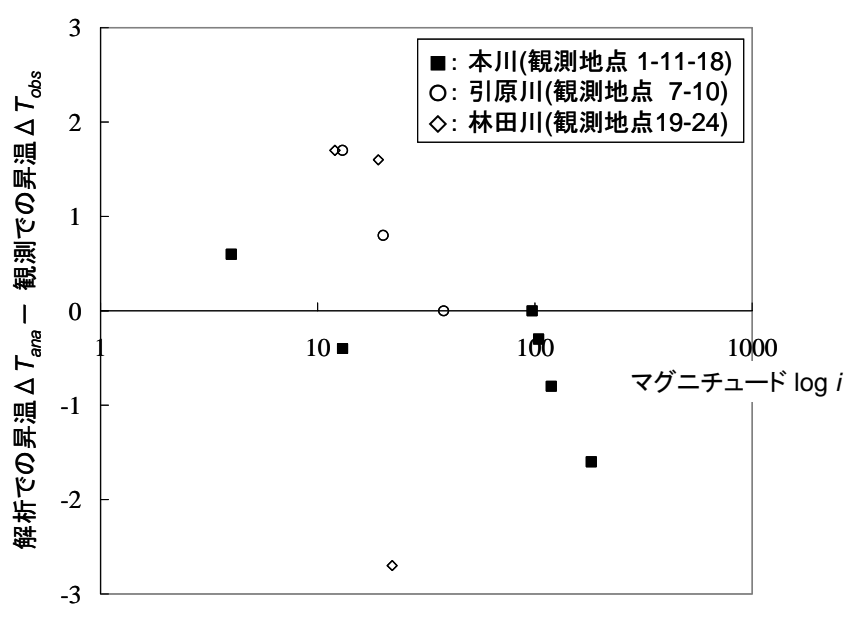

(b) 各河道区間における解析值と観測值の昇温偏差

図-6 解析水温と観測水温の比較

ち，森林や河畔林の遮蔽効果が欠落しているために，上 流域では実際よりも受熱期の水温が大きく評価され，下 流域では都市域や農地からの温められた水温が流入する 影響がモデルに取り入れられていない.

現在，河道位数・マグニチュードを用いた土地利用形 態の流域分布表現を別途検討しており ${ }^{2)}$ ，今後それら流 域の社会的・自然的要素を位数・マグニチュードを説明 変数として本モデルに組み込む予定である．また，本論 文で対象とした揖保川は地形則の適合性が非常によい流 域であった，したがって，本モデルの汎用性を向上させ るために，上述の土地利用形態に関するモデリングが完 了した後, 本モデルを日本の他の一級水系に適用してい く予定である.

\section{4. 結 論}

流域規模の河川水温予測モデルを構築した. 各河道区 間の水温変化は一次元熱保存式により表現され，各区間 の水温は流域地形則によって関連づけられる. 観測值と の比較より，解析モデルは源流から河口部への河川水温 の昇温幅を流域全体としてはよく表現していると考えら れる。しかしながら，上流域での昇温が大きく，逆に下 流域では昇温が過小評価される. 今後, 土地利用形態の 熱的影響を位数・マグニチュードを介して流域規模で表 現し，本モデルに組み入れることが課題である.

謝辞：水温観測の実施にあたり，国土交通省姫路河川国 道事務所，兵庫県龍野土木事務所，揖保川漁業協同組合 の関係各位には便宜を図って頂いた。ここに記して謝意 を表します。

\section{参考文献}

1) Miyamoto, H., Michioku, K. et al: GIS application to evaluate relation of stream order to population distribution in river basins, Proc. of 7th International Conference on Hydroinformatics, Vol.3, pp.2181-2187, 2006.

2) 宮本仁志，道奥康治他: 河道位数を用いた社会・自然環境因 子の流域分布の表現手法, 土木学会第62回年次学術講演会講 演概要CD-ROM, CS11-006, pp.447-448, 2007.

3) 宮本仁志, 道奥康治: 流域水温の連続観測と解析, 水工学論 文集，第51巻，pp.1105-1110，2007.

4) Strahler, A.N.: Quantitative geomorphology of drainage basins and channel networks, in Handbook of Applied Hydrology, Chow, V.T. ed., Section 4-II, Geology, pp.4-39-4-76, McGraw Hill, 1964.

5) Shreve, R.L.: Infinite topologically random channel network, Journal of Geology, Vol.74, 1967.

6) 新井 正, 西沢利栄: 水温論, 297p, 共立出版, 1974.

7) Webb, B.W.: Trends in stream and river temperature, Hydrological Process, Vol.10, pp.205-226, 1996.

8) Sridhar, V. et al.: Prediction of stream temperature in forested watersheds, Journal of the American Water Resources Association, Vol.40, No.1, pp.197-213, 2004.

9) Theurer, F.D. et al: Interaction between riparian vegetation, water temperature, and salmonid habitat in the Tucannon river, Water Resources Bulletin, Vol.21, No.1, pp.53-64, 1985.

10) Stefan, H.G. and Sinokrot, B.A.: Projected global Climate change impact on water temperatures in five north central U.S. streams, Climate Change, Vol.24, pp.353-381, 1993.

11) Chen, Y.D. et. al.: Stream temperature simulation of forested riparian areas: I. Watershed-scale model development, Journal of Environmental Engineering, ASCE, Vol.124, No.4, pp.304-315, 1998.

12) Chen, Y.D. et. al.: Stream temperature simulation of forested riparian areas: II. Model application, Joumal of Environmental Engineering, ASCE, Vol.124, No.4,pp.316-328, 1998.

13) Sinokrot, B.A. and Stefan, H.G.: Stream temperature dynamics: Measurements and modeling, Water Resources Research, AGU, Vol.29, No.7,pp.2299-2312, 1993.

14）土木学会水理員会: 水理公式集, 平成11年度版, p.28, 1999.

15) 岩佐義朗, 小林信久: マグニチュード理論による河道網の 連結構造に関する統計則と指標, 土木学会論文報告集, 第 273号, pp.35-46, 1978.

16) 岩佐義朗, 小林信久: マグニチュードに基づく流域地形統 計則およびその位数理論との関連性, 土木学会論文報告集, 第273号, pp.47-58, 1978.

17) Leopold, L.B.: A view of the river, Harvard University Press, 294p, 1994.

18) 土木学会水理員会: 水理公式集, 平成11年度版, p.591, 1999.

19）竹内篤雄 温度測定による流動地下水調査法, 古今書院, 1996.

(2007. 9. 30受付) 